UDC:636.09: 661.158.002.68: 638.124.4

\title{
ANALYSIS OF VETERINARY RESIDUES AND CONTAMINANTS IN HONEY
}

K. C. MIAGKA, Junior Research Fellow

State Scientific and Research Institute of Laboratory Diagnostics and Veterinary and Sanitary Expertise

E-mail:aozka@meta.ua

S. A. TKACHUK, Professor

E-mail: ohdin@ukr.net

I. S. AKATEVA, student of Master degree

The National University of Life and Environmental Sciences of Ukraine

https: / /doi.org/10.31548/bio2018.05.025

The article include analysis of residues of veterinary drugs and contaminants in honey for the period from 2012 to 2016. According to analyzes of honey samples were founded positive for containing chloramphenicol, nitrofurans (AOZ, AMOZ, SEM) and sulfametazine. Based on the results obtained, it is necessary to amend the current DSTU 4497: 2005 "Natural honey. Technical specifications" regarding the maximum levels of antibiotics for chloramphenicol and nitrofurans.

Ключові слова: honey, monitoring, antibiotics, Regulations, Directives of the European Union

Introduction. The problem of food safety - one of the components of national security. The State Service of Ukraine on Food Safety and Consumer Protection controls the level of food safety through state annual monitoring in order to confirm the safety of products of animal origin, which exported and produced in Ukraine.

Monitoring researches are divided into two state programs: state monitoring of residues of veterinary drugs and contaminants in food of animal origin; state monitoring of animal and poultry diseases of contagious etiology. The purpose of the annual monitoring is control the use of prohibited substances, compliance with the rules of used veterinary drugs, monitoring the spread of environmental pollutants and confirmed the health and welfare of animals, unprocessed food and other food products of animal origin that are subject to processing and human consumption. The monitoring of residues is based on the identification of the causes of their entry into food products, not for the fact of detecting an excess of residual quantities of the substance that is expected to investigate every case of non-compliance.

Council Directive 96/23/EC “On measures to monitor certain substances and residues thereof in live animals and animal products" [1] provided that Ukraine should develop its own national plan for monitoring groups of substances being analyzed.

Article 8 of the Law of Ukraine "On Basic Principles and Requirements for the Safety and Quality of Food Products" specifies the legal 
basis for planning and implementation of the monitoring plan for residues [2]. The monitoring plan for residues on 2017 was approved by the Order of the State Service of Ukraine on Food Safety and Consumer Protection from December, 52016 (№ 472) [3].

According to Article 29 of Directive 96/23/EC of the Central Competent Authority shall prepare draft annual residues monitoring plan with providing guarantees and effects at least equivalent to provided in abovemention Directive. According to the requirements of the European Union (EU), in accordance with Article 14 of Directive 96/23/EC [4] and Article 4 (3) of EU Regulation 882/2004 [5], the process of planning annual residue monitoring involves engagement of the State Scientific and Research Institute of Laboratory Diagnostics and Veterinary and Sanitary Expertise.

On the assessment audit by the European Commission [6], the Competent Authority doesn't have detection mechanisms the most commonly used substances (in order to plan the monitoring of residues), and some of them are not included in the annual monitoring plan due to the lack of validated analytical methods. Therefore, in the first place had problems with inappropriate sampling strategy. The Competent Authority has still not provided guidance concerning selection criteria and sampling process and selection of honey samples from several producers (not from a single producer) in the honey collection centre. This minimizes the probability of detection of incorrect results (due to incorrect mixing honey). At the same time, business operators can work on their own control programs, the Competent Authorities do not have sufficient information concerning non-compliance results of such inspections. Thus, inappropriate use of veterinary drugs in beekeeping is present, in particular, with prohibited substances: chloramphenicol, nitrofuran and metronidazole (subgroup A6).
Currently, business operators do not have implementation system on the place for trace how the apiaries supply non-compliance honey. Unlike the situation in the EU, farmers can purchase most veterinary drugs without veterinary prescriptions. Instead, national legislation requires farmers (beekeepers) to keep records concerning treatment indicating the date of treatment, the name of the drug and the withdrawal period.

According to the current requirements, the scheduled official inspections of facilities should be carried out in accordance with the registered checklists. Currently, not all checklists are approved by the Competent Authority and are not registered with the Ministry of Justice of Ukraine or are not updated, for example, to check the EU approved honey processing centers. However, this does not apply to the implementation of the HACCP system in place at the processing centers, but is a prerequisite for obtaining (issuing) an international veterinary certificate for the export of honey to EU.

At the same time, the effectiveness of the state monitoring plan is reduced due to insufficient research on some groups of substances, budget constraints, inappropriate sampling strategies and further investigations.

Purpose. To analyze the implementation of the annual State Monitoring Plan of residues of veterinary drugs and contaminants in honey for the period from 2012 to 2016 with the provision of the proposal amending the current DSTU 4497: 2005 "Natural honey. Technical specifications" regarding the acceptable levels of antibiotics.

Materials and methods of research. According to the analysis used guidelines concerning the procedures for carrying out the sampling for implementation of the State Monitoring Plan of residues of veterinary drugs and contaminants in live animals and unprocessed food products of animal origin are developed in compliance with the Laws of Ukraine «On the Basic Principles 
and Requirements for the Safety and Quality of Food Products» and "On veterinary medicine" taking into account the requirements of the Directive of the Council of 29 April 1996 № 96/23/EC, Commission Decision № 98/179 EC of 23 February 1997 [6].

To evaluate the content residues of antibiotics were used by accredited screening methods: ELISA, HPLC and confirming LC-MS/MS.

Results and Discussion. The presence of residues in animal products, it is issue that directly affects human health and public [7].

Nowadays, the use of antibiotics for the treatment and prevention of diseases of bees in Ukraine is allowed [8]. Along with the registered veterinary drugs are used other antibiotics, residual quantities of which, according to the active substances, can be found only in export batches of honey.

The European Commission Decision № 2004/432/EC dated 29 of April 2004, approved first State Monitoring Plan of residues of veterinary drugs and contaminants in honey and Ukrainian producers were allowed to export beekeeping products to EU Member States [9-10]. Currently were development Plans for state monitoring of beef, pork, poultry, geese, turkey, rabbit meat and aquaculture, milk, eggs, honey which are approved by the European Commission on April 15, 2016 № 2016/601/ EC for beef, pork, poultry, aquaculture, milk, eggs and honey.

Table 1 provides analysis for two groups of substances, A6 and B1 (antimicrobial substances) (compounds within the European Parliament and Council Regulation (EC) № 37/2010) [11] according to Annex 1 of EU Directive № 96/23 [1].

The table shows that the actual quantity of samples varied according to the National Monitoring Plan. Positive (level of detection limits) in 2012 was 1 sample of honey content nitrofuran AOZ, which is $5 \%$ of all researched samples. The researches were carried out using the ELISA screening method (detection limit $-0.4 \mu \mathrm{g} / \mathrm{kg}$ ) and the confirmatory LC-MS/MS (detection limit $0.5 \mu \mathrm{g} / \mathrm{kg}$ ). For nitrofuran AOZ in DSTU 4497: 2005 Natural honey. The technical specifications set allowable level $-0.6 \mathrm{mg} /$ $\mathrm{kg}$ [12].

From the group of substances B6, 7 samples of honey were found to be positive for the content of sulfamethasine, which was 4,7\%. The HPLC screening method (detection limit $7 \mu \mathrm{g} / \mathrm{kg}$ ) was used for the research, and LC-MS / MS (detection limit $-7 \mu \mathrm{g} / \mathrm{kg}$ ) was confirmed.

In 2013, positive result was found in 2 samples of honey for the chloramphenicol content, which was $5 \%$ of all researched samples. The researches were carried out using the ELISA screening method (detection limit $-0.05 \mu \mathrm{g} / \mathrm{kg}$ ) and the confirmatory LC-MS / MS (detection limit - $0.05 \mu \mathrm{g} /$ $\mathrm{kg})$. Drugs chloramphenicol (levomitsetin) and tetracycline belong to broad-spectrum antibiotics [13].

Chloramphenicol is one of the most toxic antibiotics for living organism, causing aplastic anemia and banned in Europe, USA and Japan. DSTU 4497:2005 Natural honey. The technical specifications set its maximum level (MRL) - $0.3 \mathrm{mg} / \mathrm{kg}$. Therefore, it is necessary to make appropriate changes to this DSTU with the possible correction of MDR for chloramphenicol and nitrofuran $\mathrm{AOZ}$ in accordance with the developed guidelines.

The positive result was 1 sample of honey for the content of metabolites of nitrofurase - SEM, which was $5 \%$. The researches were carried out using the ELISA screening method (detection limit - $0.6 \mu \mathrm{g} / \mathrm{kg}$ ) and the confirmatory LC-MS/MS (detection limit $0.6 \mu \mathrm{g} / \mathrm{kg})$.

In 2016, positive result was found in 1 sample of honey for nitrofuran AMOZ content. The researches were carried out using the ELISA screening method (detec- 
Analysis of the researched groups of substances in honey for 2012 to 2016

\begin{tabular}{|c|c|c|c|c|c|c|c|c|c|c|c|}
\hline \multirow{2}{*}{ 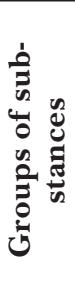 } & \multirow[t]{2}{*}{$\begin{array}{l}\text { Analyzed } \\
\text { compounds }\end{array}$} & \multicolumn{2}{|c|}{$\begin{array}{c}\text { Researched } \\
\text { samples } \\
2012 \\
\end{array}$} & \multicolumn{2}{|c|}{$\begin{array}{c}\text { Researched } \\
\text { samples } \\
2013\end{array}$} & \multicolumn{2}{|c|}{$\begin{array}{c}\text { Researched } \\
\text { samples } \\
2014\end{array}$} & \multicolumn{2}{|c|}{$\begin{array}{c}\text { Researched } \\
\text { samples } \\
2015\end{array}$} & \multicolumn{2}{|c|}{$\begin{array}{c}\text { Researched } \\
\text { samples } \\
\mathbf{2 0 1 6} \\
\end{array}$} \\
\hline & & 尽 & 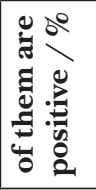 & 尝 & 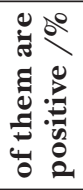 & 尝 & 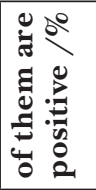 & 﨎 & 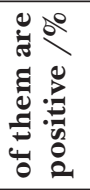 & 﨎 & 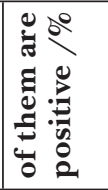 \\
\hline \multirow[t]{8}{*}{ AA6 } & Chloramphenicol & 40 & & 40 & $2 / 5$ & 42 & & 45 & & 20 & \\
\hline & AHD & 20 & & 20 & & 23 & & 25 & & 15 & \\
\hline & AMOZ & 20 & & 20 & & 23 & & 25 & & 15 & $1 / 6,7$ \\
\hline & $\mathrm{AOZ}$ & 20 & $1 / 5$ & 20 & & 23 & & 0,25 & & 15 & \\
\hline & SEM & 20 & & 20 & $1 / 5$ & 23 & & 25 & & 15 & \\
\hline & Metronidazole & & & & & & & & & 3 & \\
\hline & Dapson & 10 & & 10 & & 9 & & 10 & & 5 & \\
\hline & Colchicine & 1 & & 0 & & 10 & & 10 & & 5 & \\
\hline \multirow[t]{17}{*}{ BB1 } & Tetracycline & 150 & & 50 & & 47 & & 45 & & 27 & \\
\hline & Chlortetracycline & 150 & & 50 & & 47 & & 45 & & 27 & \\
\hline & Oxytetracycline & 150 & & 50 & & 47 & & 45 & & 27 & \\
\hline & Doxycycline & 150 & & 50 & & 47 & & 45 & & 27 & \\
\hline & Sulfatyazole & 150 & & 50 & & 47 & & 45 & & 26 & \\
\hline & Sulfadimetoxin & 150 & & 50 & & 47 & & 45 & & 26 & \\
\hline & Sulfaguanidine & 150 & & 50 & & 47 & & 45 & & 26 & \\
\hline & Сульфамеразін & 150 & & 50 & & 47 & & 45 & & 26 & \\
\hline & Sulfamethazine & 150 & $7 / 4,7$ & 50 & & 47 & & 45 & & 26 & \\
\hline & $\begin{array}{l}\text { Sulfamethoxytri- } \\
\text { pyridazine }\end{array}$ & 150 & & 50 & & 47 & & 45 & & 26 & \\
\hline & Sulfamethoxazole & 150 & & 50 & & 47 & & 45 & & 26 & \\
\hline & Sulfanilamide & 150 & & 50 & & 47 & & 45 & & 26 & \\
\hline & Streptomycin & 150 & & 50 & & 47 & & 45 & & 27 & \\
\hline & $\begin{array}{l}\text { Dihydrotreptho- } \\
\text { mycin }\end{array}$ & 150 & & 50 & & 47 & & 45 & & 27 & \\
\hline & Tylosin & 150 & & 50 & & 47 & & 45 & & 27 & \\
\hline & Nystatin & 150 & & 50 & & 47 & & 45 & & 27 & \\
\hline & Erythromycin & 150 & & 50 & & 47 & & 45 & & 27 & \\
\hline
\end{tabular}

tion limit $-0.6 \mu \mathrm{g} / \mathrm{kg}$ ) and the confirmatory LC-MS/MS (detection limit - $0.5 \mu \mathrm{g} / \mathrm{kg}$ ). For nitrofuran AOZ in DSTU 4497: 2005 Natural honey. The technical specifications set allowable level - $0.6 \mathrm{mg} / \mathrm{kg}$. Additionally, an acceptable level is required for correction action according to current confirmatory methods, including liquid chromatography.

According to RASFF's annual reports, the problem of contamination of honey with residual amounts of antimicrobial drugs remains relevant. In honey of the national 
producers often, find residues these groups of antibiotics and antimicrobial drugs, such as chloramphenicol, nitrofurans, nitromidazol, sulfonamides, tetracyclines and aminoglycosides. In Ukraine are not registered veterinary drugs for the treatment of bee that contains the above-mentioned active substances, since their use prohibited in European and Ukrainian beekeeping. Therefore, the detection of residues of these substances in honey is consequence of unauthorized use by beekeepers of contraband drugs or drugs available in retail pharmacies of humane medicine.

By the Order of the Chief State Inspector of Veterinary Medicine of Ukraine dated September 28, 2017, № 28 «On Approval of Methodological recommendations concerning consecutive actions in case of non-compline results of laboratory research (testing) of samples selected for implementation of the State Monitoring Plan for residues of veterinary drugs and contaminants in live animals and raw products of the animal origin» strict control measures applied on farms: for substances in group A - in confir- mation of positive by means of the confirmed method, as well as if during the investigation the fact of illegal processing or use of forbidden drugs is confirmed or if there are grounds for suspicion of their use - the establishment is subject to a restriction for a period of 10 days; for substances in group B - in case of confirmation of inappropriate result, the control of the establishment increases.

Conclusions and perspectives of further research:

According to the analysis of the Annual Monitoring Plan for residues of veterinary drugs and contaminants the period from 2012 to 2016 , in honey samples positive result was found for chloramphenicol, nitrofuran (AOZ, AMOZ, SEM) and sulfametazine.

Necessary to amend the current DSTU 4497: 2005 «Natural honey. Technical specifications» regarding the acceptable levels of antibiotics: chloramphenicol and nitrofuran according to methodical instructions.

Promising research considered research to obtain validation data for further evaluation nitrofuran and chloramphenicol in honey samples.

\section{Література}

1. Council Directive 96/23/EC of 29 April 1996 on measures to monitor certain substances and residues thereof in live animals and animal products, and repealing Directives 85/358/EEC and 86/469/ EEC and Decisions 89/187/EEC and 91/664/EEC : official journal of the European union. - 1996. - Vol. 25. - P. 10-32.

2. Про основні принципи та вимоги до безпечності та якості харчових продуктів [Електронний ресурс]: Закон України 771 /97-вр від 20.01.2018 - Режим доступа: http:/ / zakon3.rada.gov.ua/ laws /show/771/97-вр. - Назва з екрану.

3. Про затвердження плану державного моніторингу залишків ветеринарних препаратів та забруднювачів у живих тваринах і необроблених харчових продуктах тваринного походження на 2017 рік [Електронний ресурс]: Наказ № 472 від 05.12.2016 p.- Режим доступа: http: / / vetlabresearch.gov.ua/upload/medialibrary/5b0/Nakaz_472_2017.pdf. - Назва з екрану.

4. Commission Decision $97 / 747 / \mathrm{EC}$ of 27 October 1997 fixing the levels and frequencies of sampling provided for by Council Directive 96/23/EC for the monitoring of certain substances and residues thereof in certain animal products : official journal of the European union. - 1997. Vol. 303. - P. 12-15.

5. Regulation (EC) No 882/2004 of the European Parliament and of the Council of 29 April 2004 on official controls performed to ensure the verification of compliance with feed and food law, animal health and animal welfare rules : official journal of the European union. - 2004. - Vol. 165. - P. 1 - 52.

6. Методичні рекомендації щодо процедур здійснення відбору зразків на виконання Плану державного моніторингу залишків ветеринарних препаратів та забруднювачів у живих 
тваринах і необроблених харчових продуктах тваринного походження [Електронний ресурс]: Наказ Головного державного інспектора ветеринарної медицини України від 09 лютого 2017 року № 7. - Режим доступа: http:/ /vetlabresearch.gov.ua - Назва з екрану.

7. Commission Decision 2002/657/EC of 12 August 2002 implementing Council Directive 96/23/ EC concerning the performance of analytical methods and the interpretation of results : official journal of the European union. - 2002. - Vol. 221. - P. 8-36.

8. Про затвердження Інструкції щодо попередження та ліквідації хвороб і отруєнь бджіл [Електронний ресурс]: Наказ Головного державного інспектора ветеринарної медицини України № 131 /5322 від 30 січня 2001 року № 9. - Режим доступа: http:/ / zakon5.rada.gov.ua/ laws/show/z0131-01. - Назва з екрану.

9. Рішення Комісії від 29 квітня 2004 року № 2004/432/ ЄС про затвердження планів моніторингу залишків, представлених третіми країнами відповідно до Директиви Ради 96/23/ЄС : офіційний журнал Європейського Союзу. - №. 154. - С. 44-50.

10. Council Directive 2001 / 110/EC 20.12.2001 [Electronik resource] - Mode of access: https:/ /www. fsai.ie/uploadedFiles/Consol_Dir2001_112.pdf. - Title from the screen.

11. Commission Regulation (EU) No 37/2010 of 22 December 2009 on pharmacologically active substances and their classification regarding maximum residue limits in foodstuffs of animal origin [Electronik resource] / / Official journal of the European union. - Mode of access: http:/ / eur-lex. europa.eu/legal. - Title from the screen.

12. Мед натуральний. Технічні умови: ДСТУ 4497:2005 . / Л. Боднарчук, Н. Мулявко, Л. Хусточка, А. Черкасова, Н. Вакуленко.- Увед. вперше; чинний від 2005-12-28 - К.: Держспоживстандарт України, 2007. - 21 с. (Національний стандарт України).

13. Isenberg S.J. The fall and rise of chloramphenicol / S.J. Isenberg / / J. AAPOS. - 2003. - Vol. 7 (5). - P. 307.

\section{References}

1. Council Directive 96/23/EC of 29 April 1996 on measures to monitor certain substances and residues thereof in live animals and animal products, and repealing Directives 85/358/EEC and 86/469/EEC and Decisions 89/187/EEC and 91/664/EEC. Official journal of the European union. Vol, 125, 10-32.

2. Zakon Ukraïni "Pro osnovni principi ta vimogi do bezpechnosti ta jakosti harchovih produktiv" [The Law of Ukraine "On Basic Principles and Requirements for the Safety and Quality of Food Products"]. (n.d.) zakon3.rada.gov.ua. Retrieved from http://zakon3.rada.gov.ua/laws/ show/771/97-вр [in Ukrainian].

3. Pro zatverdzhennja planu derzhavnogo monitoringu zalishkiv veterinarnih preparativ ta zabrudnjuvachiv u zhivih tvarinah i neobroblenih harchovih produktah tvarinnogo pohodzhennja na 2017 rik [On approval of the state monitoring plan for residues of veterinary preparations and contaminants in live animals and unprocessed food of animal origin in 2017]. Order № 472 from 05.12.2016. vetlabresearch.gov.ua. Retrieved from http://vetlabresearch.gov.ua/upload/medialibrary/5b0/Nakaz_472_2017.pdf [in Ukrainian].

4. Commission Decision $97 / 747 /$ EC of 27 October 1997 fixing the levels and frequencies of sampling provided for by Council Directive 96/23/EC for the monitoring of certain substances and residues thereof in certain animal products. Official journal of the European union. Vol, 303, 12-15.

5. Regulation (EC) No 882/2004 of the European Parliament and of the Council of 29 April 2004 on official controls performed to ensure the verification of compliance with feed and food law, animal health and animal welfare rules. Official journal of the European union. Vol, 165, 1-52.

6. Metodichni rekomendaciï shhodo procedur zdijsnennja vidboru zrazkiv na vikonannja Planu derzhavnogo monitoringu zalishkiv veterinarnih preparativ ta zabrudnjuvachiv u zhivih tvarinah i neobroblenih harchovih produktah tvarinnogo pohodzhennja [Methodical recommendations on the procedures for the selection of samples for the implementation of the State monitoring plan for residues of veterinary drugs and contaminants in live animals and raw food products of animal origin]. Order of the Chief State Inspector of Veterinary Medicine of Ukraine № 7 from 09.02. 2017. vetlabresearch.gov.ua. Retrieved from http://vetlabresearch.gov.ua [in Ukrainian]. 
7. Commission Decision 2002/657/EC of 12 August 2002 implementing Council Directive 96/23/ EC concerning the performance of analytical methods and the interpretation of results. Official journal of the European union. Vol, 221,8-36.

8. Pro zatverdzhennja Instrukciï shhodo poperedzhennja ta likvidacï hvorob i otruen' bdzhil, zareestrovanij v Ministerstvi justiciï Ukraïni vid 12 ljutogo 2001 roku za № 131/5322 [On approval of the Instruction on the prevention and elimination of diseases and poisoning of bees, registered in the Ministry of Justice of Ukraine on February 12, 2001, No. 131/5322]. Order of the Chief State Inspector of Veterinary Medicine of Ukraine № 9 from 3001.2001. zakon5.rada.gov.ua. Retrieved from http://zakon5.rada.gov.ua/laws/show/z0131-01 [in Ukrainian].

9. Pro zatverdzhennja planiv monitoringu zalishkiv, predstavlenih tretimi krä̈nami vidpovidno do Direktivi Radi 96/23/ES [Approving plans for monitoring residues submitted by third countries in accordance with Council Directive 96/23 / EC]. Commission Decision №2004/432/EC from 09. 04.2004. Oficijnij Zhurnal Evropejs'kogo Sojuzu - Official journal of the European union, Vol. 154, 44-50 [in Ukrainian].

10. Council Directive 2001/110/ES 20.12.2001. fsai.ie. Retrieved from https:/ / www.fsai.ie / uploadedFiles/Consol_Dir2001_112.pdf.

11. Commission Regulation (EU) No 37/2010 of 22 December 2009 on pharmacologically active substances and their classification regarding maximum residue limits in foodstuffs of animal origin. Official journal of the European union, Vol, 15, 1-72. Retrieved from http:/ / eur-lex.europa.eu/legal.

12. Isenberg, S.J. (2003) The fall and rise of chloramphenicol. J. AAPOS. Vol, 7 (5), 307.

13. Med natural'nij. Tehnichni umovi [Honey is natural. Technical specifications]. (2007). DSTU 4497:2005 from 12th December 2005. Kyiv: Derzhspozhyvstandard Ukraine [in Ukrainian].

\section{АНОТАЦІЯ}

К. С. Млгка, С. А. Ткачук, Я. С. Акатьева. Аналіз залишків ветеринарних препаратів $i$ забруднювачів у меді. Біоресурси і природокористування. 2018. 10, № 5-6. С. 198-204. https://doi.org/10.31548/bio2018.05.025

У статті подано аналіз залишків ветеринарних препаратів $i$ забруднювачів у медi за період від 2012 до 2016 років. Згідно проведеного аналізу у зразках меду виявлено позитивний результат за вмістом хлорамфеніколу, нітрофуранів (AOZ, AMOZ, SEM) та сульфаметазину. За отриманими результатами необхідно внести зміни до чинного ДСТУ 4497:2005 «Мед натуральний. Технічні умови» шодо максимально допустимих рівнів антибіотиків для хлорамфеніколу і нітрофуранів.

Ключові слова: мед, моніторинг, антибіотики, регламенти, директиви Європейського Союзу

\section{АННОТАЦИЯ}

К. С. Мягка, С. А. Ткачук, Я. С. Акатьева. Анализ остатков ветеринарных препаратов и загрязнителей в меде. Биоресурсы и природопользование. 2018. 10, № 5-6. С. 198-204. https://doi.org/10.31548/bio2018.05.025

В статъе представлен анализ остатков ветеринарньсх препаратов и загрязнителей в меде за период с 2012 до 2016 года. Согласно проведенного анализа в образиах меда обнаружен положительный результат по содержанию хлорамфеникола, нитрофуранов (AOZ, AMOZ, SEM) и сульфаметазина. Согласно полученным результатам необходимо внести изменения в действуюшее ДСТУ 4497: 2005 «Мед натуральный. Технические условия» по максимально допустимым уровням антибиотиков для хлорамфеникола и нитрофуранов.

Ключевые слова: мед, мониторинг, антибиотики, регламенты, директивы Европейского Союза 